\title{
PENGARUH MODEL PEMBELAJARAN INKUIRI TERBIMBING TERHADAP HASIL BELAJAR KONSEPTUAL MAHASISWA SEMESTER I FKIP UNRAM
}

\author{
Heri Hadi Saputra ${ }^{1)}$, Lalu Hamdian Affandi ${ }^{2,}{ }^{, *}$, Husniati $^{3)}, \&$ Muhammad Makki ${ }^{4)}$ \\ 1), 2), 3), 4) Universitas Mataram, Mataram, Indonesia \\ E-mail: hamdian.fkip@unram.ac.id
}

\begin{tabular}{|c|c|}
\hline ARTICLE INFO & ABSTRACT \\
\hline $\begin{array}{l}\text { Article history } \\
\text { Received: May 14, } 2020 \\
\text { Revised: August 3,2020 } \\
\text { Accepted: August 12, } 2020 \\
\text { Keywords: } \\
\text { guided inquiry learning } \\
\text { models, conceptual learning } \\
\text { outcomes }\end{array}$ & 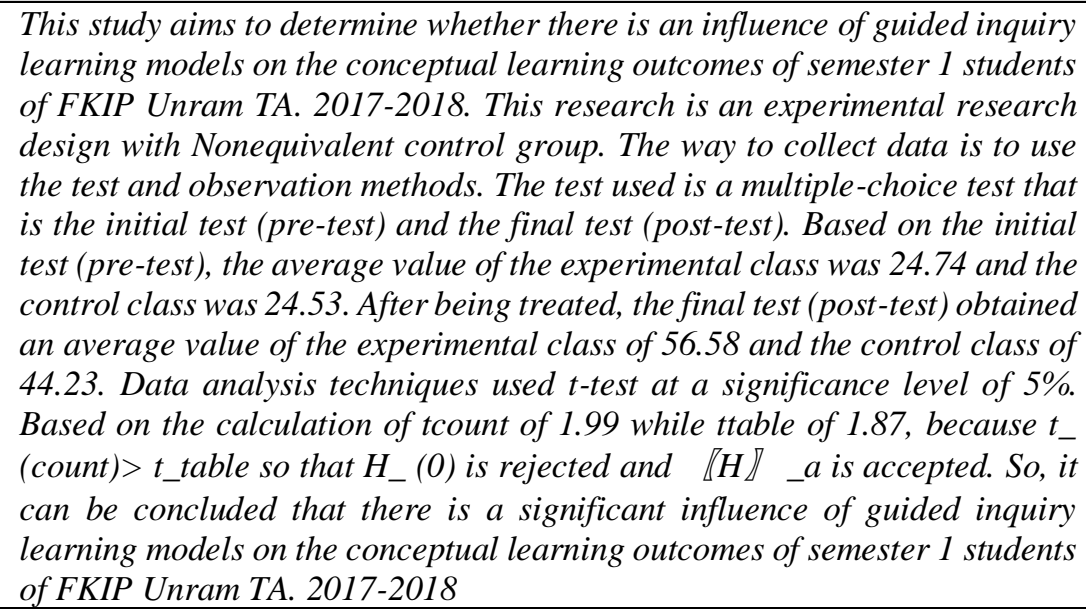 \\
\hline
\end{tabular}

\section{A. PENDAHULUAN}

Pembelajaran di perguruan tinggi pada dasarnya sudah dilaksanakan dengan metode dan model yang variatif seperti tatap muka, diskusi, penugasan, kerja proyek maupun aktifitas pengamatan laboratorium. Hal ini memungkinkan mahasiswa mendapatkan pengalaman langsung dari setiap aktifitas belajar yang mereka alami. Bahkan saat ini pembelajaran pada perguruan tinggi sudah banyak yang berbasis teknologi informasi atau e-learning. Perbaikan pada dimensi proses pembelajaran tentu bertujuan meningkatkan hasil belajar mahasiswa pada bidang yang terkait yang secara makro berarti meningkatkan kualitas output sebuah perguruan tinggi (Maulyda et al., 2019). Hasil belajar merupakan keseluruhan efek yang muncul setelah terjadinya proses pembelajaran yang meliputi perubahan kognitif yang berupa pengetahuan, pemahaman, kemampuan sintesis dan mengambil kesimpulan-kesimpulan, juga afektif yang berupa kemampuan bersikap tepat sesuai dengan keadaan dan kondisi dimana merekan berada dan memiliki kepekaaan sosial serta psikomotor yang meliputi keterampilan menerapkan 
Saputra, dkk. (2020). Pengaruh Model Pembelajaran...

pengetahuan yang mereka miliki. Keseluruhan hal tersebut merupakan domensi paling komprehensif dari hasil belajar.

Ada banyak faktor yang menentukan hasil belajar mahasiswa pada perguruan tinggi. Faktor motivasi, sarana penunjang, kualitas input dan kualitas pengajar menjadi beberapa hal yang menentukan. Namun selain itu mutu atau kualitas proses pembelajarn juga menjadi hal yang harus mendapatkan perhatian serius. Hal ini disebabkan karena pembelajaran konvensional dalam metode ceramah dan diskusi kelas cenderung menstimulasi menurunnya tingkat keterlibatan belajar mahasiswa (Maulyda et al., 2020). Dalam beberapa pengamatan di kelas yang menggunakan metode konvensional seperti yang disebutkan di atas, banyak mahasiswa hanya duduk di dalam kelas tanpa indikasi keterlibatan belajar yang maksimal. Mahasiswa tersebut lebih banyak memusatkan perhatiannya pada hal-hal lain di luar aktifitas pembelajaran seperti mengutak-atik handpone, ngobrol dengan teman, dan lain sebagainya.

Sebagai Lembaga Pendidikan Tenaga Keguruan (LPTK), Fakultas Keguruan dan Ilmu Pendidikan bertanggungjawab menyiapkan pendidik dan tenaga kependidikan yang handal dan kompetitif sehingga kualitas pendidikan di Indonesia, khususnya di NTB dapat ditingkatkan. Mutu guru yang baik tentu direpresentasikan dengan hasil belajar unggul juga. Hasil belajar unggul hanya bisa diperoleh melalui proses belajar yang juga baik. Proses belajar yang baik mensyaratkan keterlibatan penuh peserta belajar dalam hal ini mahasiswa dalam aktifitas di dalam kelas. Dan salah satu alternatif yang dapat diaplikasikan adalah menerapkan model pembelajaran inkuiri terbimbing bagi mahasiswa. Inkuiri merujuk kepada proses pembangunan pengetahuan di dalam diri peserta belajar melalui investigasi saintifik (Loyens and Rikers, 2011). Pembelajaran inkuiri dibangun dengan tujuan untuk mengajarkan mahasiswa tentang cara belajar (Arends, 2012; 341).

Hasil belajar bisa diklasifikasi menjadi aspek kognitif, afektif, dan psikomotor. Aspek kognitif berkitan dengan kemampuan individu dalam memaknai dan menggunakan informasi yang ia peroleh dalam proses pembelajaran. Aspek afektif berkaitan dengan kemampuan individu dalam mengekspresikan perasaan terhadap sebuah obyek. Sedangkan keterampilan psikomotor berkaitan dengan kemampuan individu dalam memanipulasi aspek motorik dalam dirinya untuk melakukan hal-hal tertentu. Sebelum direvisi, aspek kognitif sebagai hasil belajar terdiri dari pengetahuan, pemahaman, penerapan, analisis, sintesis, dan evaluasi. Setelah direvisi, aspek kognitif berubah menjadi aspek pengetahuan, pemahaman, penerapan, analisis dan sintesis, evaluasi, dan kreasi. Aspek kognitif tersebut seringkali disinonimkan dengan proses kognitif (Marzano and Kendall, 2007). Proses kognitif adalah aktifitas berfikir yang dilakukan oleh seorang individu. 
Obyek dari proses kognitif tersebut adalah pengetahuan (knowledge) yang terdiri dari pengetahuan factual, pengetahuan konseptual, pengetahuan prosedural, dan metakognisi. Pengetahuan factual merupakan pengetahuan dasar yang memungkinkan mahasiswa untuk mengenali suatu disiplin ilmu dan menyelesaikan masalah yang ada di dalamnya. Pengetahuan konseptual merupakan hubungan antara berbagai elemen dasar dalam suatu struktur pengetahuan yang lebih besar yang memungkinkannya untuk berfungsi dalam sebuah system. Sedangkan pengetahuan prosedural berkaitan dengan cara atau langkah-langkah dalam melakukan sesuatu. Terakhir, metakognisi merupakan pengetahuan dan kesadaran tentang proses berfikir (Marzano and Kendall, 2007; 9). Hubungan antara proses kognitif dan domain kognitif adalah proses kognitif merupakan aktifitas mental yang dilakukan individu untuk menguasai domain kognitif tertentu.

Domain hasil belajar yang dikaji dalam penelitian ini adalah pengetahuan konseptual yang berkaitan dengan serangkaian fakta dasar yang berhubungan satu sama lain sehingga membentuk struktur fungsional yang bermanfaat dalam melakukan analisis dan pemecahan masalah. Pengetahuan konseptual tersebut, bagi mahasiswa, tentunya merupakan informasi penting yang tidak bisa tidak diperhatikan dalam aktifitas intelektualnya sebagai agen perubahan. Bersama pengetahuan faktual, Marzano (2007) mengelompokkan pengetahuan konseptual dalam pengetahuan deklaratif, yaitu pengetahuan yang bersifat informatif sebagai kontras terhadap pengetahuan prosedural yang dimaknainya sebagai pengetahuan yang berorientasi proses, keterampilan, dan strategi. Dua cara yang bisa dilakukan untuk mengembangkan pengetahuan deklaratif adalah revisi dan review. Revisi dan review merupakan upaya untuk melihat kembali, memeriksa, menilai dan melakukan perubahan terhadap pengetahuan yang telah dimiliki mahasiswa melalui kegiatan analisis kesalahan (error analysis), identifikasi kesamaan dan perbedaan, dan lain sebagainya.

Model pembelajaran inkuiri adalah salah satu model pembelajaran yang dianggap sesuai untuk membantu mahasiswa membangun konsep (Arends, 2012), melatih mahasiswa berfikir kritis dan kreatif (Loyens and Rikers, 2011). Secara umum, materi pembelajaran diklasifikasi menjadi 2 bagian besar, yaitu pengetahuan deklaratif dan pengetahuan prosedural (Marzano, 2007). Pengetahuan deklaratif merupakan klasifikasi materi pembelajaran yang berkaitan dengan fakta, konsep, atau prinsip-prinsip tertentu. Model pembelajaran inkuiri adalah salah model pembelajaran yang diorientasikan untuk memberikan kesempatan kepada mahasiswa untuk membangun konsep secara mandiri atau melalui kelompok dengan memberikan makna terhadap fenomena atau kasus tertentu. Bagi mahasiswa, model 
pembelajaran inkuiri terbukti menghasilkan penguasaan materi dan prosedur ilmiah yang lebih baik dibandingkan dengan mahasiswa yang belajar dengan metode konvensional (Loyens and Rikers, 2011). Hal ini terjadi karena pada model pembelajaran inkuiri mahasiswa dilatih melakukan review dan revisi terhadap pengetahuan yang dimiliki. Aktifitas review dan revisi terhadap pengetahuan diperlukan mahasiswa untuk menghasilkan pengetahuan yang lebih akurat (Marzano, 2007).

Model pembelajaran inkuiri diorientasikan untuk melatih mahasiswa berpikir tentang cara berfikir metakognitif (Arends, 2012). Bentuk metakognitif yang dilakukan mahasiswa dalam model pembelajaran inkuiri adalah berfikir kritis dan/atau berfikir kreatif. Aktifitas berfikir kritis merupakan aktifitas berfikir yang terdiri dari 2 tahapan utama, yaitu berfikir analitis dan berfikir evaluative (Bonney and Sternberg, 2011). Berfikir analitis berkaitan dengan proses mengkalkulasi, mengestimasi, dan menemukan hubungan antara satu fenomena dengan fenomena yang lain. Sedangkan berfikir evaluative adalah proses menginvestigasi aktifitas berfikir yang telah dilakukan berdasarkan prinsip-prinsip tertentu seperti akurasi, presisi, kelogisan, dan lain sebagainya. Aktifitas berfikir analitis dilakukan oleh mahasiswa dalam model pembelajaran inkuiri ketika ia mengkaji sebuah fenomena/ kasus, merumuskan penjelasan atas fenomena/kasus yang diajukan kepadanya, atau ketika ia menentukan jenis data atau informasi yang ia butuhkan untuk menemukan penjelasan terhadap kasus atau fenomena tertentu. Aktifitas berfikir evaluatif dilakukan mahasiswa melalui aktifitas review terhadap proses inkuiri yang dilakukannya.

Model pembelajaran inkuiri dilaksanakan dalam beberapa tahapan besar yang terdiri dari (Arends, 2012; 343): memusatkan perhatian dan menjelaskan kepada siswa tentang proses inkuiri, menyajikan masalah atau kasus untuk dikaji, mendorong mahasiswa untuk memformulasikan hipotesis, mendorong mahasiswa untuk mengumpulkan data guna menguji hipotesis, membimbing mahasiswa merumuskan penjelasan atau kesimpulan, dan akhirnya membimbing mahasiswa untuk melakukan refleksi terhadap proses berfikir yang telah dilakukan. Rangkaian aktifitas di atas, tentunya masih memberikan ruang bagi guru untuk menentukan intensitas kontrol yang ia punya dalam pembelajaran. Dengan kata lain, guru memiliki ruang untuk memilih tingkat keterlibatanna dalam pembelajaran dengan mengurangi atau menambah bentuk-bentuk control terhadap aktifitas belajar mahasiswa.

Tujuan penelitian ini adalah untuk menguji pengaruh model pembelajaran inkuiri terbimbing terhadap hasil belajar mahasiswa pada mata kuliah konseptual. Penelitia berfokus pada bagaimana pengaruh model pembelajaran inkuiri terbimbing pada mata kuliah konseptual terhadap mahasiswa semester awal di FKIP Universitas Mataram. 


\section{B. METODE PENELITIAN}

Penelitian ini merupakan penelitian kuantitatif karena ingin menguji suatu teori. Pendekatan yang digunakan yaitu pendekatan kuantitatif, yaitu pendekatan penelitian yang dilaksanakan dengan mengumpulkan data-data kuantitatif atau data kualitatif yang dikuantitatifkan (Sugiyono, 2009). Dari segi metodologi, penelitian ini menggunakan metode eksperimen dengan desain nonequivalent control group. Variabel dalam penelitian ini adalah model pembelajaran inkuiri terbimbing sebagai variabel independen dan hasil belajar konseptual mahasiswa sebagai variabel dependen.

Desain nonequivalent control group merupakan salah satu bentuk aplikasi metode eksperimen yang dilaksanakan dengan pemberian perlakuan kepada sekelompok sampel yang kemudian diuji pengaruhnya. Dalam desain penelitian seperti ini, kelompok eksperimen dan kelompok kontrol tidak dipilih secara random (Sugiyono, 2009; 89). Dengan kata lain, kelompok eksperimen dan kelompok kontrol ditetapkan dengan pertimbangan-pertimbangan tertentu. Tahapan penelitian tersebut mengacu pada format desain nonequivalent control group.

\begin{tabular}{|lll|}
\hline O1 & $\mathrm{X}$ & $\mathrm{O} 2$ \\
$\mathrm{O} 3$ & & $\mathrm{O} 4$ \\
\hline
\end{tabular}

Gambar 1. Format pelaksanaan penelitian berdasarkan desain nonequivalent control group (Sugiyono, 2009; 89)

Subjek penelitian ini yaitu 2 kelompok mahasiswa sebagai sampel; yaitu kelompok eksperimen dan kelompok kontrol. Pemilihan sampel dilaksanakan secara purposif, yaitu pemilihan sampel dengan menggunakan pertimbangan-pertimbangan tertentu. Pertimbangan yang digunakan dalam penelitian ini adalah pertimbangan efisiensi dan pertimbangan fisibilitas. Alternatif yang paling mungkin dipilih adalah menetapkan kelompok sampel dari mahasiswa yang mata kuliahnya diampu oleh peneliti. Pemilihan subjek juga dilakukan dengan menggunakan kriteria yaitu kelas yang diajar pada mata kuliah konseptual, yaitu mata kuliah yang berisi pengetahuan-pengetahuan deklaratif yang termasuk dalam domain konseptual. Mata kuliah tersebut di FKIP adalah pengantar pendidikan, belajar dan pembelajaran, dan lain sebagainya.

Metode pengumpulan data dalam penelitian ini adalah tes dan observasi. Tes digunakan dalam 2 kegiatan, yaitu sebelum pemberian perlakuan (pretes) dan setelah pemberian perlakuan 
(postes). Sebelum digunakan, tes diuji validitas dan reliabilitasnya. Uji validitas dilakukan dengan rumus korelasi Pearson Product Moment. Sedangkan uji reliabilitas dilakukan menggunakan rumus split half Spearman Brown. Uji validitas dan reliabilitas tes dilaksanakan dengan bantuan software SPSS 16 for windows.

Tes yang diberikan kepada kelompok sampel terdiri dari 2 bagian, yaitu hasil pretes dan hasil postes. Hasil pretes dianalisis dengan uji t sampel independen untuk mengetahui perbedaan kondisi awal kelompok sampel. Data postes akan dianalisis dalam 2 tahap, yaitu uji asumsi dan uji hipotesis. Uji asumsi dilakukan dengan uji normalitas dan uji homogenitas. Uji normalitas dilakukan menggunakan rumus Kolmogorov Smirnov. Sedangkan uji homogenitas dilakukan dengan membandingkan varian sampel terbesar dengan varian sampel terkecil. Semua uji statistik dalam penelitian ini dilakukan dengan bantuan software SPSS 16 for windows.

\section{HASIL DAN PEMBAHASAN}

Penelitian ini menggunakan penelitian populasi dikarenakan kelas yang ditetapkajn sebagai sampel berjumlah dua yaitu kelas semester 1 reguler pagi dan semester 1 reguler sore, sedangkan dalam penelitian eksperimen ini peneliti membutuhkan kelas kontrol sebagai kelas pembanding. Sehingga seluruh populasi digunakan sebagai subjek penelitian. Untuk penentuan kelompok eksperimen dan kelompok kontrol terlebih dahulu peneliti memberikan pretest pada kedua kelompok, dari rata-rata hasil pretes yang terendah peneliti menggunakannya sebagai kelas eksperimen untuk diberi perlakuan, sedangkan kelas dengan rata-rata hasil pretes tertinggi digunakan sebagai kelas pembanding/kontrol.

Sebelum menjawab semua hipotesis dalam penelitian ini, peneliti terlebih dahulu melakukan uji validitas terhadap instrument soal hasil belajar matakuliah konseptual yang berupa soal uraian sebanyak 30 butir soal. Peneliti mengujikannya pada mahasiswa semester 1 PGSD FKIP unram dengan tingkatan yang sama. Dimana jumlah mahasiswa pada kelas sore sebanyak 43 orang dan mahasiswa kelas pagi sebanyak 39 orang. Sebelum digunakan, tes diuji validitas dan reliabilitasnya. Uji validitas dilakukan dengan rumus korelasi Pearson Product Moment. Sedangkan uji reliabilitas dilakukan menggunakan rumus split half Spearman Brown. Uji validitas dan reliabilitas tes dilaksanakan dengan bantuan software SPSS 16 for windows. Analisis uji validitas instrument soal menggunakan bantuan aplikasi Microsoft excel 2010 dan perhitungan secara manual dengan rumus Point Biserial Corelation. Peneliti menggunakan rumus ini dikarenakan pernyataan Azwar (2013: 155) mengatakan rumus Point Biserial 
Corelation dapat digunakan pada tes kemampuan kognitif yang merupakan tipe item objektif, dimana jawabannya dapat dikategorikan sebagai salah dengan nilai 0 dan benar dengan nilai 1 .

Hasil belajar mahasiswa yang dilihat dan diolah dalam penelitian ini adalah hasil belajar mata kuliah konseptual mahasiswa dengan kata lain penilaian dilakukan pada aspek kognitif, yang didapat melalui hasil pretest dan posttest mahasiswa. Hasil pretest diperoleh dari penilaian siswa mengerjakan soal pilihan ganda yang berjumlah 30 soal yang telah diuji kevalidannya. Data rata-rata hasil pretes siswa pada kedua kelas yang didapat yaitu sebesar 24,53 pada kelas kontrol dengan jumlah 39 orang meningkat menjadi 44,23 pada nilai posttest. Sedangkan pada kelas eksperimen dengan jumlah mahasiswa hadir sebanyak 41 orang diperoleh nilai pretest sebesar 24,74 dan 56,58 pada nilai posttest Untuk memastikan kesetaraan kemampuan awal, data pretes dianalisis dengan uji t. Penarikan kesimpulan didasarkan pada kaidah jika t hitung lebih kecil dari t tabel pada taraf signifikansi 5\% dengan derajat kebebasan n1+n2-2, maka hasil pretes kelompok eksperimen dan kelompok kontrol adalah setara.

Nilai t hitung sebesar 1,87 lebih kecil dari t tabel (1.99) dengan demikian dapat disimpulkan bahwa hasil pretes dan postes kelompok eksperimen dan kelompok kontrol adalah setara. Dilanjutkan dengan memberikan perlakuan dengan model pembelajaran inkuiri terbimbing pada kelas eksperimen. Yang telah dijelaskan pada pembahasan bagian $\mathbf{A}$. Selanjutnya pemberian metode biasa/konvensional pada kelas kontrol selama 4 kali pertemuan. Langkah selanjutnya adalah melakukan perhitungan hasil posttest, dan didapat perbedaan hasil belajar siswa pada kelas eksperimen dan kelas kontrol.

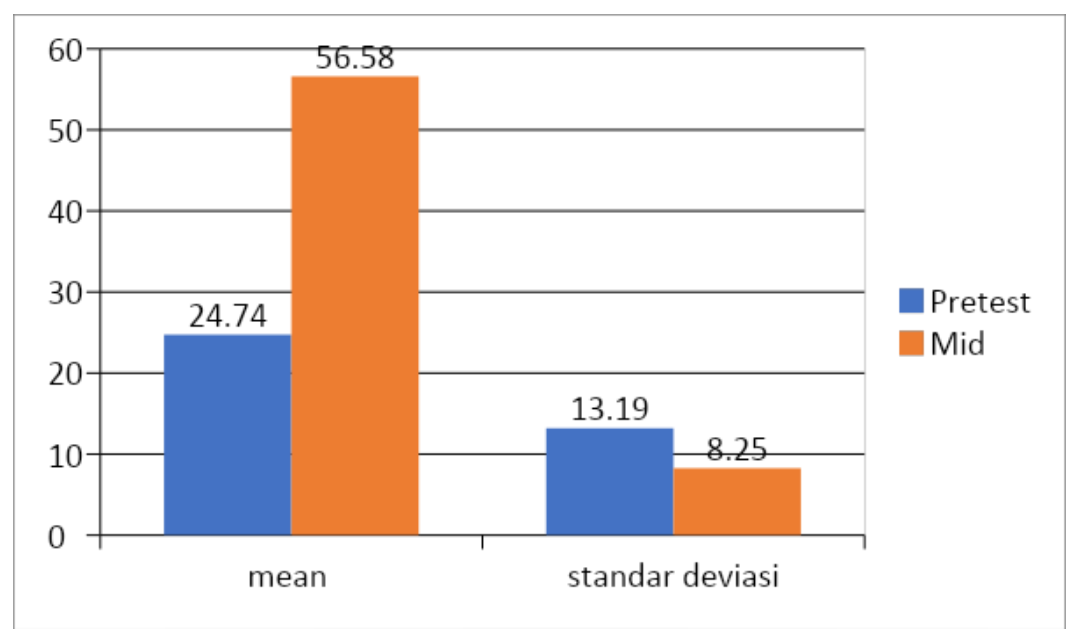

Gambar 2. Grafik Pretest-Postes Hasil Belajar Kelas Eksperimen

Dapat terlihat pada Gambar 2 kelas eksperimen, rata-rata hasil belajar mengalami peningkatan. Kelas eksperimen mengalami peningkatan hasil belajar dibandingkan kelas kontrol. Dimana terlebih dahulu dilakukan pemberian pretest dengan hasil rata-rata sebesar 
24,74 setelah melakukan uji prasyarat, kemudian kelas eksperimen diberi perlakuan dengan metode picture and picture sebanyak empat kali pertemuan. Langkah selanjutnya pemberian postest dengan hasil rata-rata yang ditemukan ternyata mengalami peningkatan sebesar 56,58.

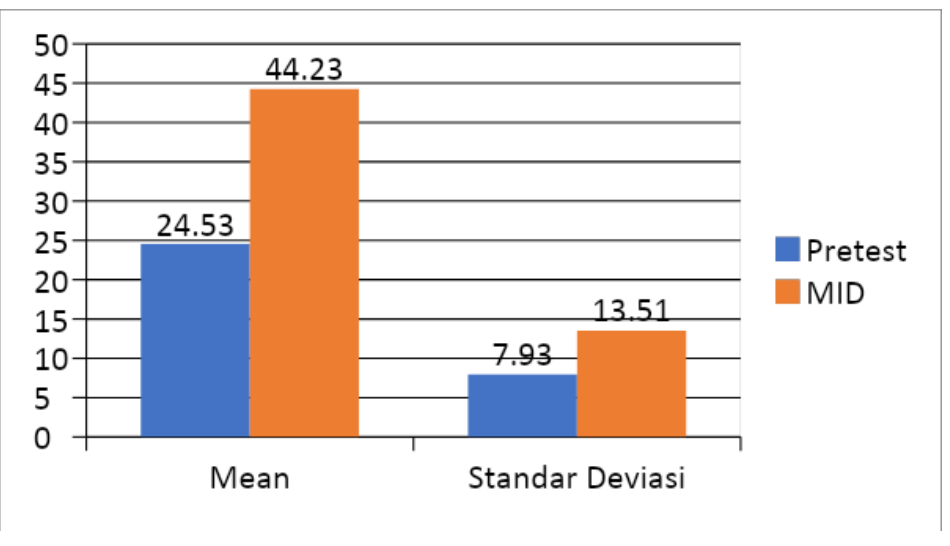

Gambar 3. Grafik Pretest-Postes Hasil Belajar Kelas Kontrol

Kelas kontrol mengalami peningkatan hasil belajar dibandingkan yang lebih rendah dibandingkan dengan kelas eksperimen. Dimana terlebih dahulu dilakukan pemberian pretest dengan hasil rata-rata sebesar 24,53 setelah melakukan uji prasyarat, kemudian kelas eksperimen diberi perlakuan dengan metode picture and picture sebanyak empat kali pertemuan. Langkah selanjutnya pemberian postest dengan hasil rata-rata yang ditemukan ternyata mengalami peningkatan sebesar 44,23.

Perbedaan hasil belajar pada kelas kontrol dan kelas eksperimen disebabkan karena perbedaan model pembelajaran yang diterapkan model pembelajaran inkuiri menggunakan paradigma student centred yang menjadikan mahasiswa sebagai subjek pembelajaran sehingga mereka dapat mengkonstruksi pengetahuan dengan cara yang lebih baik. Sedangkan model pembelajaran teacher centred memunculkan sikap pasif mahasiwa pada saat proses pembelajaran berlangsung. Penggunaan model pembelajaran yang kedua ini memiliki beberapa kelemahan diantaranya:

1. Materi yang dapat dikuasai mahasiswa sebagai hasil dari teacher centred akan terbatas pada apa yang dikuasai dosen. Sebab apa yang diberikan dosen adalah apa yang dikuasainya, sehingga apa yang dikuasai mahasiswa pun akan tergantung pada apa yang dikuasai dosen.

2. Dalam penyajiannya dosen lebih mengandalkan bahasa verbal dan mahasiswa hanya mengandalkan kemampuan auditifnya (kemampuan mendengar). Sedangkan, disadari bahwa setiap mahasiswa memiliki kemampuan yang tidak sama, termasuk ketajaman menangkap materi pembelajaran melalui pendengarannya. 
Sangat sulit untuk mengetahui apakah seluruh mahasiswa sudah mengerti apa yang dijelaskan atau belum. Walaupun ketika mahasiswa diberikan kesempatan untuk bertanya, dan tidak ada seorangpun yang bertanya, semua itu tidak menjamin mahasiswa seluruhnya sudah paham. Berbeda dengan model pembelajaran inkuiri yang memberi peluang bagai mahsiswa untuk mengkonstruksi pengetahuannya secara lebih baik. Hal ini sesuai dengan pernyataan yang mengatakan: Keterampilan penting yang diperoleh mahasiswa dalam pembelajaran inkuiri adalah berfikir kritis, self-directed learning, serta keterampilan komunikasi yang terbuka dan jelas (Swanson, Ahmad, and Radisevic, 2014).

\section{SIMPULAN}

Berdasarkan data hasil penelitian yang telah dikemukakan sebelumnya, maka dapat disimpulan hal sebagai berikut yakni, terdapat pengaruh penggunaan model pembelajaran inkuiri terbimbing terhadap hasil belajar konseptual mahasiswa semester 1 FKIP Unram, hal ini ditunjukan dengan rata-rata hasil posttest pada kelas eksperimen yang mengalami peningkatan yakni dari 24,74 (pretest) ke 56,58 (posttest) sedangkan kelas kontrol yakni dari 24,53 (pretest) ke 44,23 (posttest). Berdasarkan data hasil postest dari kedua kelas dan diuji menggunakan uji-t diperoleh $t_{\text {hitung }}=1,99$, sedangkan $t_{\text {tabel }}=1,84$ pada taraf signifikan $5 \%$ sehingga $t_{\text {hitung }}(1,99)>t_{\text {tabel }}(1,84)$. Sehingga dari penelitian ini $\mathrm{H}_{\mathrm{a}}$ dterima dan $\mathrm{H}_{\mathrm{o}}$ ditolak dapat disimpulkan bahwa ada pengaruh model pembelajaran terbimbing terhadap hasil belajar konseptual mahasiswa semester 1 FKIP Unram TA. 2017-2018.

Penelitian ini menyarankan agar Model Pembelajaran inkuiri terbimbing dijadikan salah satu alternatif model pembelajaran guna memperoleh hasil belajar konseptual mahasiswa yang lebih baik terutama pada semester-semester awal yang banyak memberikan materi konseptual kepada mahasiswa. Selain ini penelitan ini juga merekomendasikan penelitian yang lebih mendalam dan konprehensif dengan kajian dan variabel model pembelajaran yang lebih variatif agar ditemukan lebih banyak model bagi sistem pembelajaran pada perguruan tinggi yang pada akhirnya mampu meningkatkan prestasi belajar mahasiwa.

\section{DAFTAR PUSTAKA}

Arends, R.I. 2012. Learning to Teach, Ninth Edition. New York; McGraw-Hill.

Bonney, C.R., and Sternberg, R.J. 2011. Learning to Think Critically. In Richard E. Mayer and Patricia A. Alexander (eds.). Handbook of Research on Learning and Instruction. p. 166-196. New York; Routledge

Creswell, J.W. 2012. Educational Research, Fourth Edition. Boston; Pearson Education Inc. 
Gilardi, S., and Loza, E. 2009. Inquiry Based Learning and Undergraduates' Professional Identity Development: Assessment of Field Research-Based Course. Innovation in Higher Education, 34; 245-256

Hannah, Ingram, Kerr, and Kelly, 2014. Inquiry-Based Learning for Interprofessional Education. In Patrick Blessinger and John M. Carfora (eds.). Inquiry-Based Learning for the Arts, Humanities, and Social Science: a Conceptual and Practical Resource for Educators. p. 105-125. Bingley, UK; Emerald Group Publishing Limited

Loyens, S.M., and Rikers, R.M.J.P. 2011. Instruction Based on Inquiry. In Richard E. Mayer and Patricia A. Alexander (eds.). Handbook of Research on Learning and Instruction. p. 361-381. New York; Routledge

Maulyda, M. A., Hidayati, V. R., Rosyidah, A. N. K., \& Nurmawanti, I. (2019). Problemsolving ability of primary school teachers based on Polya's method in Mataram City. PYTHAGORAS: Jurnal Pendidikan Matematika, 14(2), 139-149. https://doi.org/https://doi.org/10.21831/pg.v14i2.28686

Maulyda, M. A., Radiusman, R., Erfan, M., Darmiany, D., \& Asrin, A. (2020). The effectiveness of the use lecture journal books in improving learning outcome of PGSD student's. Premiere Educandum: Jurnal Pendidikan Dasar Dan Pembelajaran, 10(1), 1. https://doi.org/10.25273/pe.v10i1.5183

Marzano, R.J. 2007. The Art and Science of Teaching: A Comprehensive Framework for Effective Teaching. Alexandria, VA; ASCD

Marzano, R.J., and Kendall, J.S. 2007. The New Taxonomy of Educational Objectives, Second Edition. Thousand Oaks, CA; Corwin Press

Marzano, R.J., Pickering, D.J., Arredondo, D.E., Blackburn, G.J., Brandt, R.S., Moffet, C.A., Paynter, D.E., Pollock, J.E., and Whisler., J.S. Dimension of Learning: Teacher's Manual, Second Edition. Alexandria, VA; ASCD and Mcrel

Moreno, R. 2010. Educational Psychology. Denver; John Wiley \& Sons Inc.

Slavin, R.E. 2006. Educational Psychology: Theory and Practices, Eighth Edition. Boston; Pearson Education Inc.

Sugiyono. 2009. Metode Penelitian Administrasi. Bandung; Alfabeta

Swanson, C.C., Ahmad, A., and Radisevic, I. 2014. A First-Year Social Science Inquiry Course: The Interplay of Inquiry and Metacognition to Enhance Student Learning. In Patrick Blessinger and John M. Carfora (eds.). Inquiry-Based Learning for the 
Penulisl, dkk. (tahun). 3 kata judul...(diisi oleh editor)

Arts, Humanities, and Social Science: A Conceptual and Practical Resource for Educators. p. 53-73. Bingley, UK; Emerald Group Publishing Limited. 